\title{
THE ROLE OF THE TAX BURDEN IN THE TAXATION OF UKRAINE
}

\author{
Olha MELNYK', \\ Vinnytsya State Agrarian University, Ukraine
}

\begin{abstract}
The purpose of the paper is to underline and present the important of the tax burden in the taxation of Ukraine and to show its influence on the profit of the enterprises. The problem of the optimization of the taxes is closely connected with two factors. The first factor is that the aim of the tax system is to fill the state budget. The second factor is to make fovourible conditions for business to prosper. Also, the aim of the research is epy development of scientific and methodological foundations of practical recommendations on the management of the tax burden with an economic entity on the basis of more efficient use of production resources. To achieve this aim the amendments of the Tax Code and the introduction of new rates and taxes were considered, which affects the activities of the company. also the main criteria of the indicators for assessing the tax burden on the company were formed. The object of research is the process of management of the tax burden on the basis of increase of efficiency of use of industrial resources of the enterprise. The subject of the study is the theoretical and methodological and practical aspects of the tax burden, and its calculation methods for reduction and increase, based on the characteristics of business administration. Methodology. The theoretical base of the issue is taken from the economic bases, the works of the native and foreign scientists on the topic of the influence of the taxation on the work of the enterprises, their profit, the analysis of the statistic data during the last few years. To achieve these goals the following methods were used: a method of system analysis and synthesis, methods of statistical groupings, economic and mathematical, logical and comparative analysis. The information base for writing articles constitutes a legal and regulatory acts of Ukraine, the statistical data of the State Committee of Statistics of Ukraine, the reporting enterprises in Ukraine. Results. The main theoretical result is the justification of the main principles of making business taking into consideration the taxation of the country, and make it profitable. Practical implications/value. The practical value of the results are expressed in using the special methods in practical activity of the enterprise on the base of making the mechanism of the management of tax paying with increase the a efficiency of all the resources of the company.
\end{abstract}

Key words: tax burden, taxation, revenues, state budget, GDP.

JEL Classification: E62, H21, H71

\section{Introduction}

One of the most important components that optimizes the tax system of Ukraine is a radical increase of the positive impact on full-fledged market and all market infrastructure. Also it influences on a favorable investment climate in the formal economy and on ensuring the efficient and safe investment, creating mechanisms for protection impairment funds and competitive environment as the implementation mechanism for the most effective business decisions.

The optimal level of tax burden is and important relevant factor for the dynamics of business activity and for the development of production and the economy as a whole, as well as socio - political stability.

\section{Review of recent sources of research and publications}

The theoretical basis and practical issues of taxation are covered in the works of many local and foreign authors.
The issue of tax burden, its impact on economic activity and income taxpayers, causes and consequences of its uneven distribution between economic trends and ways to change are discussed in the works of local economists A. Sokolovska, T. Kalinesk, L.Shabysta, V. Vyshnevskyy, Z. Varnaliy, V. Savchenko, O. Malyshkina .

The authors of recent publications that have examined the issue of taxes and tax burden in Ukraine are I. Bilous, G. Datsenko, N. Korkun, O. Korotevych, N. Lohanova, Yu. Panura, M. Stepura, O. Tymchenko.

During the existence of the tax system many foreign and domestic methods to determine the tax burden developed, but in spite of that common approaches still exist. The majority of scientists consider the tax burden on the state level, but some of them consider it at the level of the enterprise. However, taking into account specific national tax system, studies need to be updated and systematization of theoretical and practical attempts to assess the level of tax burden on businesses. The aim of the article is to

\footnotetext{
Corresponding author:

${ }^{1}$ Departament of International Economy, Vinnytsya State Agrarian University.

E-mail: epidersia@ukr.net
} 
improve the methods of analysis of tax burden business enterprises, to identify possible indicators for its evaluation at the macro level and its impact on the revitalization of the national economy.

\section{The state budget revenues}

During the last years fiscal policy was conducted by the Government of Ukraine against the background of an unstable global economy and volatility in international financial markets.

Filling the budget revenues occurred in a reformed tax law, in accordance with the Tax Code of Ukraine.

Among the features of filling the revenue part of the budget in 2014-2015 are the following:

- reduction in tax rate;

- increase the excised tax on alcohol, alcoholic beverages, tobacco, petrol and diesel;

- change directions of paying the value added tax, including processors, who carried out the supply of milk, raw milk, dairy products, meat, meat products and other products processing animals, 30 percent of the positive difference between the amount of tax liability and the amount of tax loan paid into a special fund of the State budget of Ukraine and 70 percent the special accounts opened by them in the State treasury, which helped protect farmers - milk producers with providing real receiving compensation for donated raw materials; provide support for farmers favorable purchasing prices for milk; encourage the development of dairy farming in Ukraine; prevent a rapid rise in prices for dairy products for consumers of the country;

- cancellation from July 1, 2012 the zero rate of tax to VAT transactions for the supply of natural gas imported into the customs territory UkrayinyNAK "Naftogaz Ukraine";

- introduce a special procedure for consideration of the negative value of the object of taxation on income tax results in the next tax periods;

- enrollment fees for the provision of some administrative services to the general fund of the state budget;

- introduction of charging court fees, which was introduced from 01.11.2011 by the Law of Ukraine of 08.07.2011 №3674-VI "About Court Fee" instead of revenue to pay costs for technical support proceedings in the courts.

The adoption and implementation of the new Customs Code of Ukraine in 2012 provided growth of state budget revenues without hindering legitimate import-export operations. New Customs Code of Ukraine meets the International Convention on the Simplification and Harmonization of Customs Procedures.

In order to stimulate the development of small and medium business in Ukraine as an important factor of social and economic stability of the state in the period of financial and economic crisis and to implement the program of economic reforms of the President of Ukraine for 2010-2014"Prosperous Society, Competitive Economy, Effective State" Law of Ukraine from 04.11.2011 № 4014IV «About Amendments to the Tax Code of Ukraine and some other legislative acts of Ukraine on the simplified system of taxation, accounting and reporting" and from 22.03.2012 № 4618-VI «About the development and state support of small and medium enterprises in Ukraine" were established.

These laws improved and simplified tax system with changes in tax legislation and the business environment, ensure its conformity with modern trends of tax policy, prevent tax evasion, in particular, provided favorable conditions for development of small and medium enterprises; ensured the competitiveness of small and medium enterprises; the conditions to stimulate investment and innovation activity and employment growth through the development of entrepreneurial initiative of citizens.

\section{The influence of the tax burden on the economy of the country}

Research tax burden on the economy is important, because of the number of taxes, their types and rates, differentiation, availability and validity of tax benefits, which depends largely on their possible impact on stimulation economic actors, their capacity for accumulation and investment, determines the extent of structural change in the economy and increase its effectiveness (Melnyk, 2005).

The tax burden as a fiscal indicator shows the degree of centralization and socialization of GDP created in the budgetary system of the country and socialized redistribution of GDP through the system with providing economic agents of social benefits, direct and indirect financial assistance. As a price index it describes the weight of the tax burden obligatory payments to any resultant source (company revenue, profits, labor costs, costs of households, etc.).

In Ukraine today there is no general methodic calculating of the tax burden. There is no official statistics of this indicator, there is only a few scattered data, which indirectly can make his mark. There is a wide range of ideas about evaluation methods and indicators of the tax burden.

Generally, most definitions of " tax on- loading " is limited to its calculation algorithm. The methodological basis of the analysis of the tax burden is a general scheme of the macroeconomic turnover, which is based on the system of national accounts. Circulation revenues and expenses is associated with economic actors taxes at different stages - production, creation, distribution and redistribution of income.

In the international system of national accounts classification applicable taxes is based on the tax base and covers taxes on products for production, on income and deductions for social insurance (Melnyk, 2005).

At every stage of circulation revenues, as reflected in national accounts, groups of different taxes are formed, the total amount of which is related to synthesis of economic indicators - GDP, and it can characterize the level of tax burden on the economy (Table 1,2). 
Apparently, according to the system of national accounts at the production stage the proportion of taxes an average of $6.01 \%$. The lowest value set in $2005-5.31 \%$, most $-6.9 \%$ in 2000 growth rate of output growth rates correspond to the total amount of taxes is illustrated in Fig. 1.

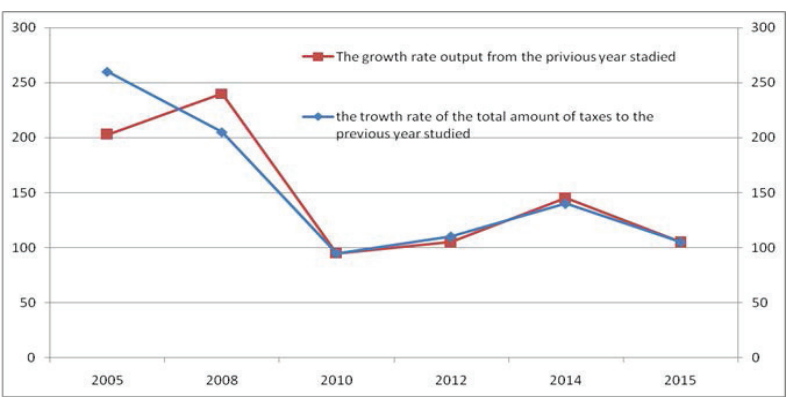

Fig. 1. Continued growth in output and the total amount of taxes for the period 2005-2015 biennium

Source: Calculated by the authors according to the State Statistics Service of Ukraine (http://www.ukrstat.gov.ua/) and the State Treasury Service of Ukraine (http://www.treasury.gov.ua/)

As can be seen from the table 2 stage distribution and use of income share of tax increases and the average value is $13.38 \%$. If we consider the 2015 figure is the proportion of tax is lower than in 2014 at $1.57 \%$, as compared to 2000 $4.01 \%$.

Also it must be considered as part of the tax burden on the social security payments that make up an average of $11.52 \%$. The highest figure was recorded in 2005 at a rate of $12.21 \%$, which is $0.76 \%$ less than in 2015 .

If the total amount of taxes to grieve at all stages of circulation revenues and expenses of economic agents the average of the tax burden for the period 2000-2015 is $30.91 \%$. Moreover, statistics indicate a decrease in the share of taxes in national accounts in 2015 compared to 2000 as illustrated in Fig. 2.

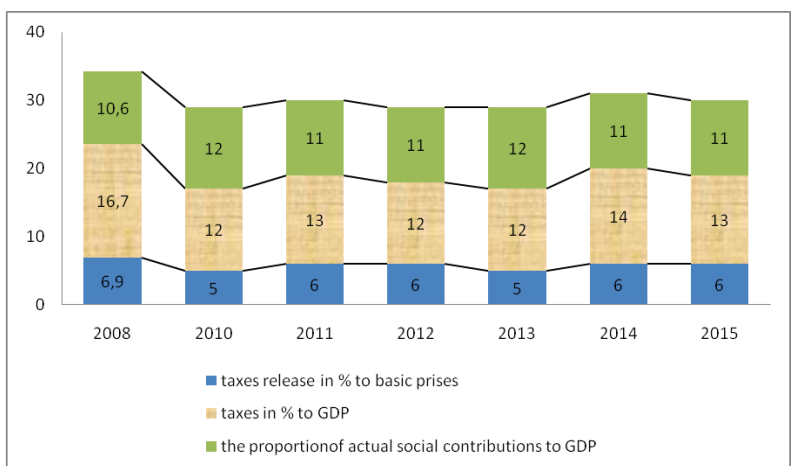

Source: Calculated by the authors according to the State Statistics Service of Ukraine (http://www.ukrstat.gov.ua/) and the State Treasury Service of Ukraine (http://www.treasury.gov.ua/)

\section{The range of the tax burden in different countries}

The tax burden varies significantly across countries (Table 3). Analysis of the share of taxes in GDP of several countries in Europe and Asia shows that Ukraine in terms of tax burden does not exceed this figure in other countries, and in many of them the share of taxes in GDP is much higher. For example, in Sweden, Italy, Belgium, France, Denmark, the figure is in the range $45-47 \%$, Greece, Great Britain, Iceland, Slovenia, Germany - 35-37\%, Chile, Korea, Turkey - 21-27\% (http://www.org/ statistics/).

Table 1

The evolution of the system of national accounts at the manufacturing stage

\begin{tabular}{|l|c|c|c|c|c|c|c|}
\hline & 2000 & 2005 & 2008 & 2010 & 2012 & 2014 & 2015 \\
\hline Production at basic prices, mln & 373893 & 995630 & 2072172 & 1955685 & 2388289 & 2895283 & 3150653 \\
\hline Taxes on products , mln. UAH & 27338 & 54183 & 126425 & 119988 & 130957 & 184195 & 200912 \\
\hline Subsidies on products , mln. UAH & 1530 & 1332 & 2545 & 3124 & 2547 & 1917 & 3973 \\
\hline Taxes less subsidies ,mln. UAH & 25808 & 52851 & 123880 & 116864 & 128410 & 182278 & 196939 \\
\hline Taxes as\% of production at basic prices & 6,90 & 5,31 & 5,98 & 5,98 & 5,38 & 6,30 & 6,25 \\
\hline
\end{tabular}

Source: Calculated by the authors according to the State Statistics Service of Ukraine (http://www.ukrstat.gov.ua/) and the State Treasury Service of Ukraine (http://www.treasury.gov.ua/)

Table 2

The evolution of the system of national accounts at the stage of distribution and use of proceeds

\begin{tabular}{|l|c|c|c|c|c|c|c|}
\hline & 2000 & 2005 & 2008 & 2009 & 2012 & 2014 & 2015 \\
\hline GDP at market prices , mln. UAH & 170070 & 441452 & 948056 & 913345 & 1082569 & 1302079 & 1459096 \\
\hline Taxes on production and imports , mln. UAH & 31707 & 62777 & 142599 & 134842 & 149602 & 204136 & 226743 \\
\hline Subsidies on production, mln. UAH & 3184 & 6700 & 25817 & 19516 & 18263 & 17562 & 40603 \\
\hline Taxes less subsidies million. USD. & 28523 & 56077 & 116782 & 115326 & 131339 & 186574 & 186140 \\
\hline Taxes as\% of GDP & 16,77 & 12,70 & 12,32 & 12,63 & 12,13 & 14,33 & 12,76 \\
\hline Actual employers contributions to social insurance & 18044 & 53891 & 114222 & 103998 & 125882 & 146945 & 167055 \\
\hline $\begin{array}{l}\text { The share of actual social insurance contributions } \\
\text { hectares of GDP }\end{array}$ & 10,61 & 12,21 & 12,05 & 11,39 & 11,63 & 11,29 & 11,45 \\
\hline Total taxes less subsidies \% & 34,28 & 30,22 & 30,34 & 29,99 & 29,14 & 31,91 & 30,46 \\
\hline
\end{tabular}

Source: Calculated by the authors according to the State Statistics Service of Ukraine (http://www.ukrstat.gov.ua/) and the State Treasury Service of Ukraine (http://www.treasury.gov.ua/) 
In Ukraine, the average level of taxation consists of a situation where many taxpayers avoid paying taxes, the economy still operates loss-making enterprises, some businesses in arrears in the payment of taxes, and the amount of tax benefits are comparable to the amount of tax revenue (Malyshkin A., 2013).

It is advisable to note that the tax burden is important in terms of tax administration and may be a direct target of this administration, and it is not only a quantitative characteristic as the subject of theoretical analysis, that is a study of the effects of explicit and implicit impact on the welfare of their tax payers.

Many publications are devoted to the measurement of the tax burden on business. Their analysis shows that the formula for calculating the relevant indicator appears on the amount of taxes included in the budget now under applicable law, without regard to effect their shifting as a result of which the formal (defined by law) and real taxpayers do not match. A price mechanism taxes formally entered into the budget entity may be partially or fully translated into goods and services to buyers or sellers of inputs.

Professor A. Sokolovskaya notes that impersonal taxes paid to the budget of the company, can not be compared with taxes on individual. After the first of them really affects the company as a separate business entity, reducing working capital and limiting investment opportunities in retained earnings development of production, higher wages working, and so on. It is noted that these arguments can not deny the need to study the effect of shifting the tax burden from one company to the other, and ultimately - to individuals.

\section{Conclusions}

Evaluation of the tax burden in Ukraine shows that taxation is moderate compared to the market of developed countries, however, worth noting that the total amount of tax burden computed with the ratio of tax revenues for a certain period of GDP in Ukraine does not reflect the real situation, and therefore can not be the basis for addressing the ways and methods of improving taxation system in the context of economic growth.

Investigating the tax burden on the company proposed to conduct in order to determine the factors that influence the shifting of taxes possible direction of shifting (that is, the area of distribution tax), the circumstances and reasons that prevent it shifting, and its implications for business enterprises, defining urgency and calls for further in-depth analytical research in this direction.

Table 3

Taxes as a share of GDP in OECD countries as a percentage [http://www.ukrstat.gov.ua/]

\begin{tabular}{|c|c|c|c|c|c|c|c|c|c|c|c|}
\hline Years & \multirow{2}{*}{2005} & \multirow{2}{*}{2006} & \multirow{2}{*}{2007} & \multirow{2}{*}{2008} & \multirow{2}{*}{2009} & \multirow{2}{*}{2010} & \multirow{2}{*}{2011} & \multirow{2}{*}{2012} & \multirow{2}{*}{2013} & \multirow{2}{*}{2014} & \multirow{2}{*}{2015} \\
\hline Countried & & & & & & & & & & & \\
\hline Chili & 18,98 & 18,72 & 19,06 & 20,71 & 22,00 & 22,78 & 21,40 & 17,21 & 19,53 & 21,21 & 20,84 \\
\hline Korea & 23,21 & 24,01 & 23,27 & 23,96 & 25,05 & 26,52 & 26,52 & 25,53 & 25,06 & 25,91 & 26,81 \\
\hline Turkey & 24,62 & 25,93 & 24,07 & 24,26 & 24,52 & 24,08 & 24,22 & 24,64 & 26,20 & 27,83 & 27,66 \\
\hline Switzerland & 28,93 & 28,24 & 27,83 & 28,11 & 27,91 & 27,69 & 28,13 & 28,74 & 28,05 & 28,55 & 28,17 \\
\hline Ireland & 27,73 & 28,15 & 29,60 & 30,13 & 31,60 & 31,12 & 29,23 & 27,59 & 27,38 & 27,90 & 28,28 \\
\hline Canada & 32,81 & 32,67 & 32,47 & 32,32 & 32,60 & 32,27 & 31,59 & 31,42 & 30,56 & 30,39 & 30,74 \\
\hline Israel & 36,31 & 35,55 & 35,51 & 35,68 & 36,00 & 36,39 & 33,79 & 31,35 & 32,42 & 32,60 & 31,58 \\
\hline Estonia & 31,02 & 30,76 & 30,56 & 30,64 & 30,68 & 31,43 & 31,85 & 35,35 & 34,01 & 32,28 & 32,52 \\
\hline Spain & 34,42 & 34,04 & 34,88 & 36,04 & 36,91 & 37,29 & 33,15 & 30,92 & 32,50 & 32,15 & 32,87 \\
\hline Greece & 33,86 & 32,31 & 31,50 & 32,14 & 31,62 & 32,47 & 32,10 & 30,49 & 31,65 & 32,17 & 33,76 \\
\hline Great Britain & 34,83 & 34,44 & 34,91 & 35,43 & 36,27 & 35,75 & 35,81 & 34,17 & 34,86 & 35,75 & 35,25 \\
\hline $\begin{array}{c}\text { Czech } \\
\text { Republic }\end{array}$ & 34,88 & 35,82 & 36,26 & 36,10 & 35,64 & 35,87 & 34,98 & 33,76 & 33,95 & 34,93 & 35,50 \\
\hline Iceland & 35,33 & 36,74 & 37,90 & 40,69 & 41,49 & 40,64 & 36,72 & 33,88 & 35,18 & 35,98 & 37,19 \\
\hline Slovenia & 37,85 & 38,04 & 38,13 & 38,62 & 38,26 & 37,66 & 37,07 & 36,99 & 38,13 & 37,05 & 37,38 \\
\hline Germany & 35,63 & 35,78 & 35,02 & 35,03 & 35,66 & 36,10 & 36,49 & 37,37 & 36,17 & 36,93 & 37,59 \\
\hline Luxembourg & 39,32 & 38,13 & 37,35 & 37,58 & 35,86 & 35,63 & 37,34 & 39,05 & 37,34 & 37,00 & 37,76 \\
\hline Hungary & 37,98 & 37,91 & 37,66 & 37,31 & 37,29 & 40,33 & 40,14 & 39,85 & 38,04 & 37,05 & 38,92 \\
\hline Norway & 43,09 & 42,32 & 43,05 & 43,20 & 43,47 & 42,93 & 42,12 & 41,99 & 42,64 & 42,51 & 42,21 \\
\hline Austria & 43,63 & 43,47 & 43,04 & 42,11 & 41,53 & 41,77 & 42,75 & 42,45 & 42,20 & 42,32 & 43,18 \\
\hline Finland & 44,68 & 44,11 & 43,47 & 43,91 & 43,81 & 42,97 & 42,90 & 42,85 & 42,51 & 43,68 & 44,08 \\
\hline Sweden & 47,46 & 47,77 & 48,06 & 48,87 & 48,32 & 47,36 & 46,44 & 46,56 & 45,42 & 44,19 & 44,31 \\
\hline Italy & 41,09 & 41,53 & 40,76 & 40,59 & 42,08 & 43,19 & 43,03 & 43,39 & 42,96 & 43,01 & 44,42 \\
\hline Belgium & 44,74 & 44,26 & 44,40 & 44,47 & 44,11 & 43,60 & 43,95 & 43,10 & 43,54 & 44,06 & 45,28 \\
\hline France & 43,52 & 43,34 & 43,57 & 44,10 & 44,39 & 43,67 & 43,51 & 42,46 & 42,87 & 44,07 & 45,29 \\
\hline Denmark & 47,86 & 48,02 & 49,03 & 50,83 & 49,62 & 48,90 & 47,76 & 47,76 & 47,42 & 47,68 & 47,96 \\
\hline
\end{tabular}




\section{References}

Belous, I. (2012). The value of tax leverage in the system of revitalization of the national economy. Foreign trade , economics, finance, law, issue 1, p. 127-130.

Chernyshev, M. (2014). Improved methods of calculating the tax burden of VAT. Economy \& State, issue 10, p. 148-151.

Datsenko, G.V. \& Pichkur, I.V. (2013). Tax burden as a criterion for the efficiency of tax policy. Accounting, control and analysis in the management of business activities: scientific research journal Ukrainian scientific-practical Internet conference, p. 321-324.

Korkuna, N.M. \& Tsehelyk, G.G. (2013). Economic-mathematical methods and models to improve the mechanism of tax burden. Actual problems of economy, issue 12, p. 246-253.

Korotkevich, A.V. (2012). Potential risks reducing the tax burden in terms of the introduction of the Tax Code of Ukraine. Formation of market relations in Ukraine, issue 6, p. 25-29.

Lohanova, N. (2012). Tax burden in Ukraine as a factor of impact on the economic viability. Economist, issue 4, p. 46-49.

Malyshkin, A. (2013). Accounting and auditing Taxes and Ukraine: theory, methodology, practice. Monograph, $373 \mathrm{p}$.

Melnyk, T. (2005). Effect internal taxes on foreign economy Ukraine. The Economist, issue 12, p. 42-45.

Panura, V. (2012). Innovative approaches to the assessment of the tax burden in times of economic instability. Problems of science, issue 11, p. 42-47.

Savchenko, V.F. (2011). Evaluation of the tax burden in Ukraine. Economic Journal - XXI, issue 9/10, p. 25-28.

Sokolovskaya, A.M. (2008). Methodological and methodical aspects of determination of the tax burden on labor, capital and consumption. Finance of Ukraine, issue 1, p. 65-76.

Stepura, M.M. (2011). Optimization of the tax burden in Ukraine under uncertainty and risk. Economy \& State, issue 3, p. 78-80.

Timchenko, A., Kondratenko, M.V. (2012). The tax burden on legal entities in Ukraine and its impact on economic growth. Finance of Ukraine, issue 10, p. 34-43.

State Statistics Service of Ukraine. [Electronic resource]. - Retrieved from: http://www.ukrstat.gov.ua/

State Exchequer Service of Ukraine. [Electronic resource]. - Retrieved from: http://www.treasury.gov.ua/

\section{Ольга МЕЛЬНИК}

\section{РОЛЬ НАЛОГОВОЙ НАГРУЗКИ В СИСТЕМЕ НАЛОГООБЛОЖЕНИЯ УКРАИНЫ}

Аннотация. Целью исследования есть подчеркнуть и представить важность налоговой нагрузки в системе налогообложения Украины, показать ее влияние на прибыль субъектов хозяйственной деятельности страны. Проблема оптимизации налогообложения связана с двумя факторами, а именно: как наполнить бюджет страны и в то же время создать благоприятные условия для деятельности предприятий, для их развития. Также, целью исследования есть разработка научно-методических основ, практических рекомендаций на счет управления налоговой нагрузкой субъекта хозяйственной деятельности на базе повышения эффективности использования производственных ресурсов. Для достижения данной цели было рассмотрено изменения Налогового Кодекса, введение новых ставок и налогов, которые влияют на деятельность предприятия, также, были сформированы основные критерия т показатели оценки налоговой нагрузки на предприятие. Объектом исследования есть процесс управления налоговой нагрузкой на основе увеличения эффективности использования производственных ресурсов предприятия. Предметом исследования есть теоретико-методологические и практические аспекты управления налоговой нагрузкой, ее расчет и методы уменьшения и увеличения, исходя из особенностей введения хозяйственной деятельности. Методика. Теоретическую основу исследования составляют основы экономической теории, научные труды отечественных и зарубежных ученых по теме влияния налогообложения на работу предприятий, их прибыль, анализ статистических данных в сравнении нескольких лет. Для достижения поставленных целей использовались следующие методы: метод системного анализа и обобщения, методы статистических группирований, экономико-математического, логического и сравнительного анализа. Информационную базу для написания статьи составляют законодательные и нормативные акты Украины, статистические данные государственного комитета статистики Украины, отчетные данные предприятий Украины. Метод системного анализа и обобщения использовался при исследовании теоретических подходов к выбору эффективных методов управления налоговой нагрузкой предприятия в практике хозяйственной деятельности. Методы экономико-математического, логического и сравнительного анализа использовались при обобщении, обработке и аналитической оценке первичных фактических материалов. Результаты. Основным теоретическим результатом является обоснова- 
ние основных принципов ведения хозяйственной деятельности предприятия с учетом налоговой системы страны, при этом сохраняя прибыльность предприятия. Результатом исследования также есть усовершенствование подходов к поискам резервов на предприятиях для уменьшения налоговой нагрузки, классификация факторов, которые влияют на уровень налоговых платежей субъекта хозяйственной деятельности. Кроме того, обращено внимание на организационную структуру предприятия, в основе которой есть налоговый менеджмент, который позволяет установить связь между отделами предприятия в процессе планирования, анализа и контроля использования ресурсов с целью снижения налоговой нагрузки. Практическое значение результатов выражается в использовании определенных методик в практической деятельности субъекта хозяйственной деятельности на базе формирования механизма управления налоговыми платежами методом увеличения эффективности использования производственных ресурсов предприятия. 